


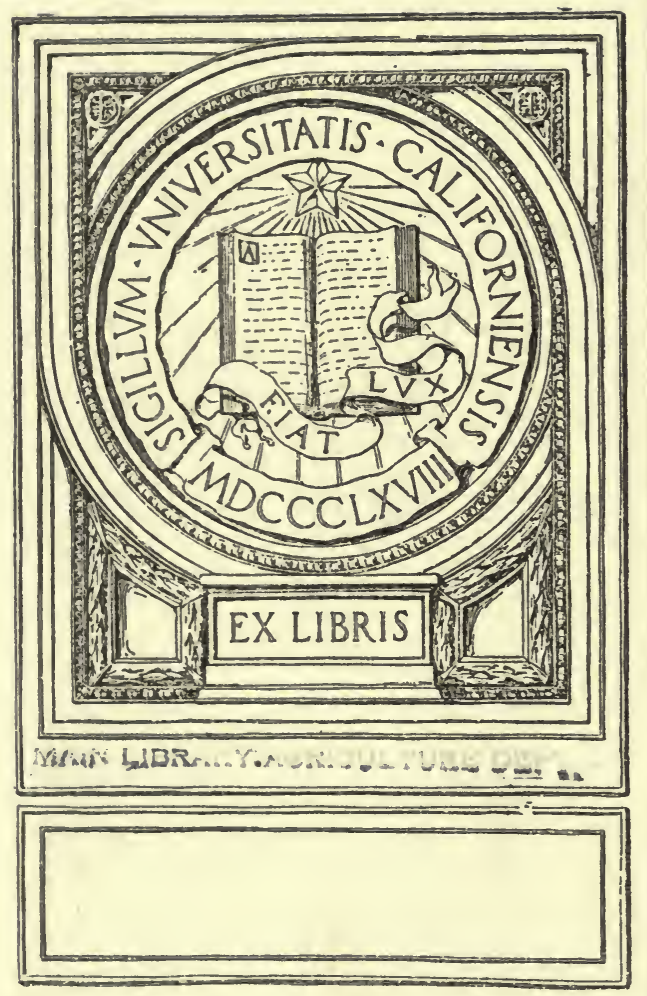


Digitized by the Internet Archive in 2007 with funding from Microsoft Corporation 





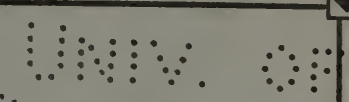

PROVINCE OF BRITISH ÖEUUHBA:

DEPARTMENT OF AGRICULTURE

(LIVE STOCK BRANCH)

\section{BUTTER-MAKING ON THE FARM}

BULLETIN No. 71

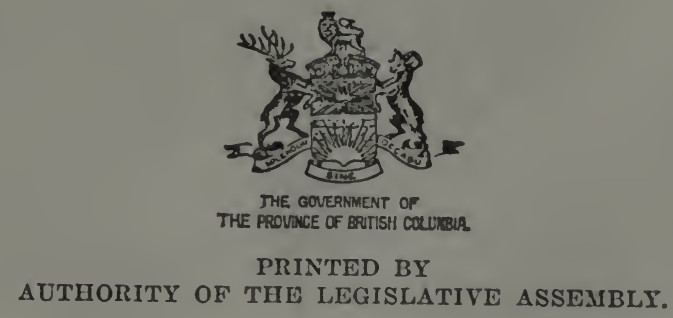

VICTORIA, B.C. :

Printed by Williax H. Cellin, Printer to the King's Most Excellent Majesty. 1916. 



\title{
PROVINCE OF BRITISH COI_LMEIA
}

\author{
DEPARTMENT OF AGRICULTURE
}

(LIVE STOCK BRANCH)

\section{BUTTER-MAKING ON THE FARM}

\section{BULLETIN No. 71}

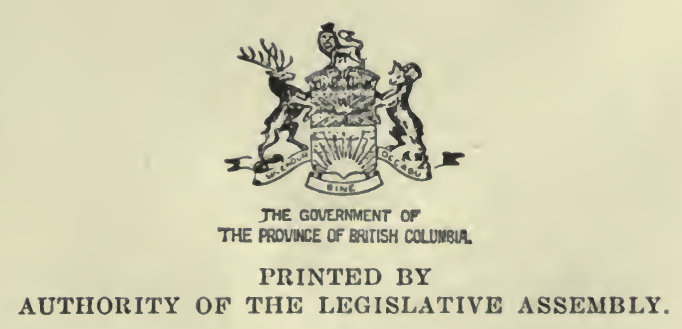

VICTORIA, B.C.:

Printed by Williax II. CulliN, I'rinter to the King's Most Excellent Majesty. 
MAIN LIBRARY.AGRICULTURE DERIP.

$$
\begin{aligned}
& \text { S141 } \\
& \text { A4 } \\
& n 0.71-89
\end{aligned}
$$




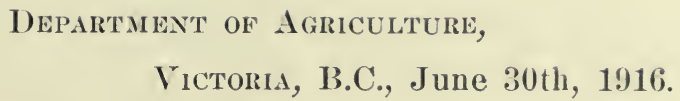

To His Honour Frank Strluman Barnard,

Lieutenant-Governor of the Province of British Columbia.

May it please Your Hoyour:

I have the honour to submit for your consideration herewith Bulletin No. 71, "Isutter-making on the Farm," prepared by T. A. F. Wiancko, Provincial Dairy Instructor, under the direction of Wm. E. Scott, Deputy Minister of Agriculture.

\section{WM. MANSON,}

Minister of Agriculture. 



\section{Departalent of Agriculture, \\ Victoris, B.C., June 30th, 1916.}

Hon. Wm. Manson,

Minister of Agriculture, Victoria, B.C.

Sir,-I have the honour to submit herewith for your approval Bulletin No. 71, entitled "Butter-making on the Farm," which has been compiled by T. A. F. Wiancko, Provincial Dairy Instructor, of the Live Stock Branch of the Agricultural Department.

I have the honour to be,

Sir,

Your obedient servant,

WM. E. SCOTT,

Deputy Minister of Agriculture. 



\title{
PROVINCE OF BRITISH COLUMBIA.
}

\section{DEPARTMENT OF AGRICULTURE (LIVE STOCK BRANCH).}

\author{
HON. WM. MANSON, \\ Minister of Agriculture. \\ WM. E. SCOTT, \\ Deputy Minister of Agriculture.
}

W. T. MCDONALD, B.S.A., M.S.A.,

Live Stock Commissioner.

*H. RIVE, B.S.A.,

Chief Dairy Instructor.

J. R. TERRY,

Chicf Poultry Instructor.

* WM. NEWTON, B.S.A., Soil and Crop Instructor.

H. F. WALKER, B.S.A., Agriculturist.

A. KNIGHT, V.S., Chief Veterinary Inspcetor.

W. W. ALTON, V.S.,

Vetcrinary Inspector.
S. H. HOPKINS, B.S.A., Assistant Live Stock Commissioner.

T. A. F. WIANCKO, Dairy Instructor.

H. E. UPTON, Poultry Instructor.

H. O. ENGLISH, B.A., B.S.A., Soil and Crop Instructor.

* S. F. DUNLOP, B.S.A., Assistant Agriculturist.

S. A. K. WHITE, V.S., Veterinary Inspector. B. R. ILSLEY, Y.S., Veterinary Inspector.

WM. J. BONAVIA, Secretary to the Department.

* Granted leave of absence for overseas service. 


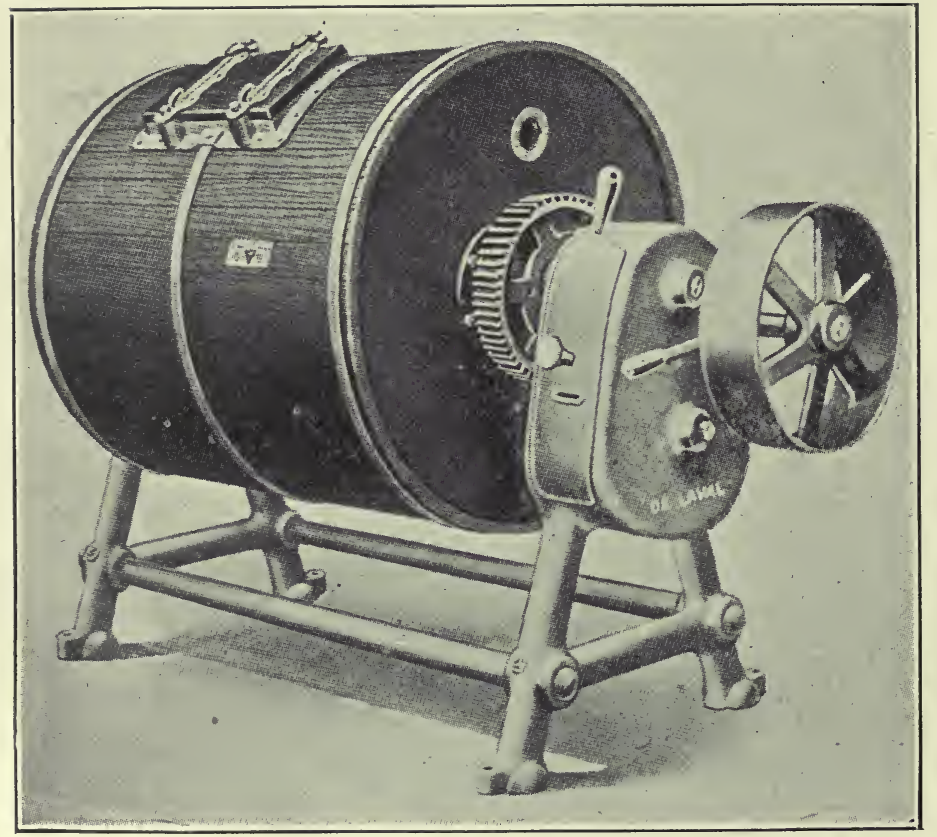

Fig. 1. Combined churn and worker. 


\section{BUTTER-MAKING ON THE FARM.}

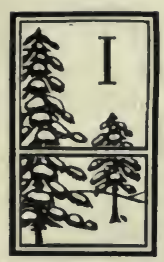

$T$ will not be denied by any one who is at all familiar with dairy conditions in British Columbia that there is great room for improvement in the quality of a large proportion of our farm-made butter. If all the dairy butter was of finest quality the increase in consumption would be very great, and better average prices would prevail for all butter, and thus a tremendous impetus would be given the dairy industry as a whole. Creamery butter, from the fact that it has been made by those who have been well instructed in the art of buttermaking in well-equipped, sanitary creameries, is of uniform grade and quality, and therefore has a ready sale at top prices.

The creamery butter-maker is supplied with a full outfit of utensils and apparatus, which enable him to recover a maximum quantity of butter from the cream. He gives careful attention to the ripening of the cream, so as to develop desirable flavours, and proper temperatures are carefully maintained during the ripening process and at the time of churning. No guesswork is allowed at any stage of the process, and the butter-maker who knows his business sees to it that the butter is carefully and thoroughly worked, packed in a neat and attractive way, and kept in clean and sanitary storage until marketed.

The case is different, however, with those who make butter on the farms, where a large part of the butter of this Province is still being made. There is a great lack of proper equipment in the way of proper dairy-houses, utensils, apparatus, and cooling facilities, and a general lack of knowledge of the underlying principles of the art of making butter of first quality.

While on some farms excellent work is done and a choice article is made, which brings a fancy price, yet, through ignorance of correct methods of manufacture and of the demands of the market, and in many instances through carelessness, the great bulk of farm-made butter fails to bring the price it should, entailing a loss on the farmers of this Province which in the aggregate is enormous. It is for the benefit of this latter class that this bulletin is written, with the hope that some suggestions may be given and some ideas advanced which will serve to improve the methods of the dairyman and increase his profits.

\section{DEFECTS IN DAIRY BUTTER.}

(1.) Undesirable flavours, such as rancid, unclean, cowy, fishy, weedy, tallowy. etc. :

(2.) Lack of uniformity-oversalting, undersalting, insufficient working, overworking, too much or too little colour:

(3.) Churned from thin, overripe cream at too high a temperature, causing the retention of too much buttermllk, and resulting in a general lack of body and texture:

(4.) Unsuitable packages and too many different styles.

\section{CAUSES OF UNDESIRABLE FLAVOURS.}

(1.) Milking in unclean stables:

(2.) Cow's udders and teats in an unclean condition at milking-time:

(3.) Foods that impart volatile flavours, such as turnips, onions, cabbage, spolled and fermented feeds, etc.:

(4.) Separating the milk in an unsuitable place, where there is lack of pure air and ventilation : 
(5.) Improperly cleaned separators and milking utensils:

(6.) Keeping the cream or butter at too warm temperature and in poorly constructed, ill-ventilated storage:

(7.) Cream too old or too ripe before churning and too much buttermilk retained in the butter:

(8.) Impure water, cows drinking from stagnant ponds or the seepage from barnyards :

(9.) Result of the growth of injurious bacteria, yeasts, and moulds.

\section{BACTERIA.}

Like other plants, bacteria require food, warmth, and moisture for growth. They absorb their food from the material in which they grow. The food elements they require are present in the constituents of milk, and they are in a readily available state. Nitrogen, carbon, oxygen, and mineral matter are essential and are furnished by the casein, milk-sugar, and mineral salts.

\section{SOURCES OF BACTERIA IN MILK.}

Milk may be contaminated by bacteria from within the udder, or introduced into the milk by dust falling from the stable air, by hair, small particles of skin, or manure falling into the milk-pail from the flanks and udder of the cow, and by dirt from the hands and clothing of the milkers. The greater part of this filthy matter dissolves in the milk, giving it not only undesirable odours and taints, but also inoculating it with the various kinds of bacteria. These germs may also have been gathered from stagnant water, muddy pools, or miry yards. While the majority of them may not be disease-producing or especially harmful, should they be transmitted to the human system, yet, to say the least, they are factors in bringing about decomposition of the milk.

\section{HOW TO KEEP MILK PURE.}

Filth and disease germs go hand in hand; the same carelessness that allows the one is likely to give access to the other. Hence it is of the highest importance that the cow and her surroundings be kept as clean as possible. This can be accomplished by brushing off all the loose dirt and dust from the flanks and udder. This will take but a moment, and will prevent large quantities of filth from getting into the milk. The amount of dirt that gets into the milk is one of the chief causes of its rapid spoiling, and the contamination from dissolved filth can never be entirely eliminated.

\section{THE HERD.}

The first requisite for pure milk is healthy cows. Any animal suspected of being sick or out of condition should be at once separated from the herd and not allowed to remain near the dairy. Milk should never be used until five days after calving, nor from a sick cow nor one with a diseased udder.

\section{BARNS AND STABLES.}

Costly barns or stables are not essential to the production of clean milk or to the maintenance of a dairy herd at its highest efficiency. To obtain the best results, however, it is important that the cows be kept comfortable at all times. The barnyard should be well drained and covered with gravel, stone, or cement. The contamination which a cow gets from muddy "manury" barn lots and stagnant pools of water is especially bad. A tight, reasonably smooth floor, with a gutter suitably located, should be provided, and the stable thoroughly cleaned and swept at least twice daily. It is advisable to haul the manure directly to the field from the barn, but if this is not feasible it should be removed at least 40 feet from the barn. In no case must it be allowed to accumulate against or near the dairy-barn. 


\section{LIGHT AND PURE AIR.}

'Two things almost universally lacking, or, at least, inadequately supplled in dairy-barns, are light and pure air. These are easily obtained, and although absolutely essential to the best health of the herd and the economic production of clean milk, they are rarely appreciated.

Most dairy-barns do not contain suflicient windows. If a barn is already built, more windows can easily be provided. There should be 4 square feet of glass for each animal, and the lighting so provided that the sunlight may reach all parts of the stable some time during the day.

Some good system of ventilation should be provided, as the cow's feed cannot be properly digested and assimilated without an abundance of oxygen; and unless this is supplied a great waste of good food, as well as impaired health of the cow, will result.

To be sanitary, a dairy-barn should be whitewashed at least twice a year. An interior with a few boards or poles laid overhead at irregular intervals, with hay or straw hanging through, and with the sides in no better condition, cannot be properly whitewashed, and is one of the most prolific sources of dust, cobwebs, and dirt, which fall into the milk laden with injurious bacteria. The ceiling should be tight, excluding all dust and chaff from above, and the sides smooth, thus affording a firm surface to which whitewash can cling.

\section{PLATFORMS.}

It is of the utmost importance in keeping cows clean that the platform on which they stand should be of the proper length. If too short the cows cannot lie down comfortably, and if too long the droppings will fall on the rear of the platform and the cows will become soiled when lying down. A good arrangement is some form of movable stanchion or manger, so that the length of the platform can be adjusted to suit the length of each individual cow.

\section{MILKING.}

The quality of the milk is also dependent to a great extent upon the milker. His personal habits largely determine the cleanliness of the product. He should be personally clean, have cleanly habits, and enjoy perfect health. A bucket of clean water and a clean cloth should always be used to moisten the flanks and udder of the cow before milking. When these parts are dampened, the dust, dandruff, and loose hairs will adhere to them and minimum amounts fall into the milk.

Milking should never be done just after handling hay or bedding, or when the stable is full of dust or bad odours from any cause, for dust is one of the most common sources of the bacteria found in milk, and bad odours may readily be absorbed by the milk.

A milk-pail with a small opening (Fig. 2), or one with the top partially covered, is always advisable. The pail should be held close to the udder so as to expose the milk to the air as little as possible. The further the streams fall and the more they spray, the more dirt and bacteria they collect. Milking should be done only with clean, dry hands. Milking with wet hands is filthy. The clothing of the milker should be of washable material and kept properly clean.

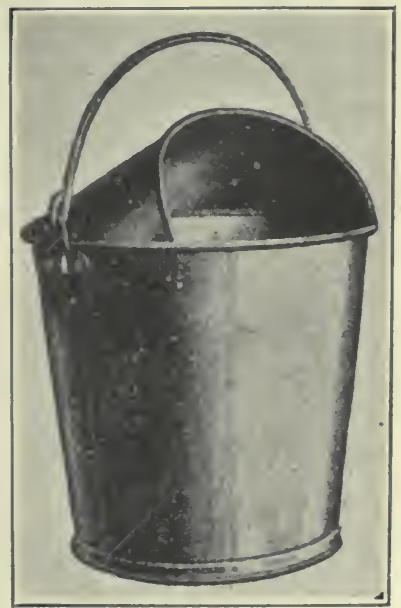

Fig. 2. Sanitary milk-pail. 


\section{STRAINING.}

The milk should be removed from the stable to a clean, airy place, such as a dairy-house which is free from dust, flies, and bad odours, as soon as possible after it is drawn, and strained at once.

A good milk-strainer (Fig. 3) should be simple in its construction; all parts of it should be easily accessible for thorough cleaning, its meshes should be fine enough to remove all the solid foreign

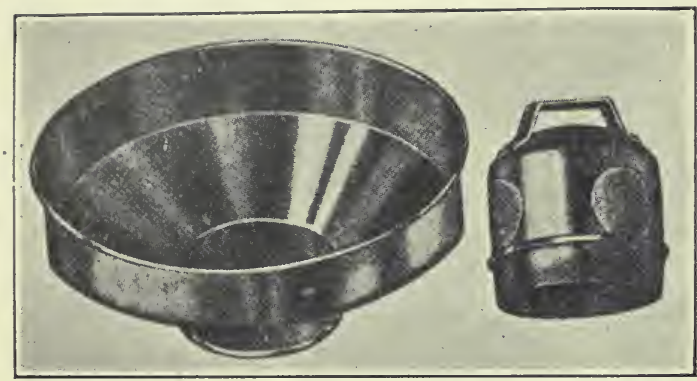

Fig. 3. Milk-strainer, showing centre removed. matter, and at the same time to allow the milk to pass through reasouably fast. All things considered, a strainer consisting of a fine wire gauze and four layers of cheese-cloth is most practical and efficient.

The cause of many of the most costly disturbances in dairying, such as rapid souring, bad odours, and all sorts of abnormal fermentations, has been traced to the filthy condition of the milk-strainer. The strainer immediately after use should be thoroughly rinsed in cold or lukewarm water; then washed in hot water to which a small quantity of some good washing-powder has been added; then rinsed in boilng water, sterilized by exposure to live steam, or by boiling in clean water and dried in the sunlight, or in a dust-free, clean room.

\section{THE DAIRY-HOUSE.}

This building should be convenient to but entirely separate from the barn where the milking is done. It should be just large enough for actual needs, so that it caunot be used as a general store-room. A cement floor is to be recommended wherever possible, and should be constructed with a slope towards a gutter com. municating with a drain situated on the outside of the building, so that the waste water can be carried off for a considerable distance. The walls and ceiling should be smooth, so that they can be quickly and thoroughly cleaned. There should be plenty of light and ventilation. The windows and doors should be screened summer and winter. There should be convenient arrangements for washing, scalding, and drying dairy utensils, and an abundant supply of pure water for cooling the milk or cream.

In case a special dairy-house cannot be provided, the milk or cream should be handled and stored in a clean, light, and well-rentilated place, free from strong odours of any kind. A cellar is usually a very poor place for this purpose, especially if also used for storing vegetables.

\section{SKIMMING THE MILK.}

When good, clean milk has been secured, the next operation is to separate the cream from the milk. This may be accomplished by either of three methods now commonly in use-riz., shallow pans, deep setting, and the cream-separator.

\section{THE SHALLOW PAN.}

The best results from using shallow pans are to be obtained by setting the milk immediately after milking, placing the pans in a clean, well-ventilated room, where the temperature ranges from $50^{\circ}$ to $60^{\circ}$ Fahr. Skimming should take place about twenty-four to forty-eight hours from the time of setting, and can best be accom- 
plished by loosening the cream from the sides of the pan with a thin-bladed knife; and by tilting the pan on the edge of the crean-can just sufficient to allow the milk to first wet the rim of the pan, the cream by the aid of the knife may be easily and quickly guided into the cream-can. If possible, no milk should be taken with the cream, as it dilutes it and makes it more difficult to churu.

Uniformly good results by this method canmot be obtained, for the reason that the milk being spread out in a thin sheet is exposed to the air, so that it is readily affected by atmospheric changes. The large surface of milk exposed in the pans. and the length of time that it stands, also favour the absorption of odours and infection that come from impure air, dust, and dirt. The comparatively high temperature of the milk and cream encourages souring and bad flavours, and often results in the cream becoming leathery and lumpy, and these in turn cause heary loss of fat in the buttermilk.

This method of creaming milk is best suited to a place where only one or two cows are kept. It may also be used where neither ice nor cold water are available for deep setting.

\section{DEEP SETTING.}

This method has decided advantages over the shallow-pan system where an abundance of very cold running water, or water and ice, are available, in that there is less milk surface exposed to the air, and the low temperature at which the milk is held ensures an improved quality of cream, butter, and skim-milk under average conditions.

The equipment necessary for efficient creaming by this method is a suitable water-tight box or tank sufficiently large and deep to hold the creamer-cans and allow space for the cooling water, or water and ice.

The warm milk should be immediately strained into the cans and the cans lowered into the water, which should reach up as far as the milk. To do efficient ereaming, the water should not be above $45^{\circ}$ Fahr., and as much lower us possible.

The best type of can (Fig. 4) to use is one with a slanting bottom, with a faucet to draw off the skimmilk. The slant carries away any sediment and permits the remoral of all the skim-milk.

The milk should always set twenty-four hours before the skim-milk is drawn, and in winter thirtysix hours is better. The longer period yields a richer cream, which may be churned at a lower temperature, resulting in a firmer-grained butter and in less loss in the skim-milk.

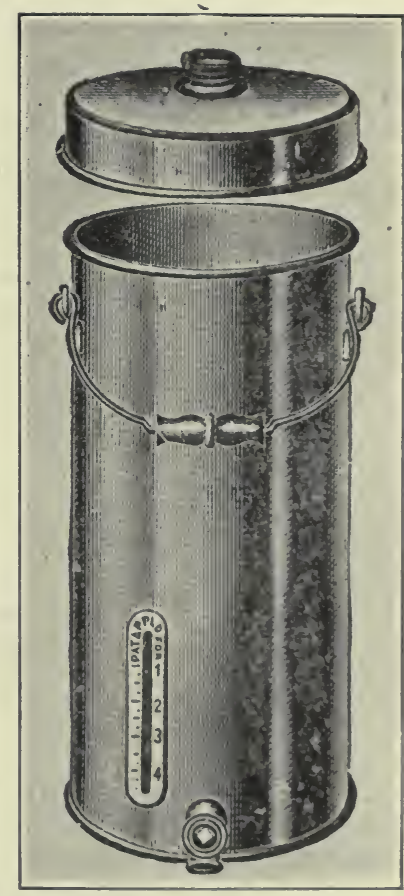

Fig. 4. Deep-setting can.

Setting the cans in cold air in winter will not prove nearly as effective in raising the cream as setting them in cold water, even though the temperature of the surrounding air is near the freezing-point.

\section{THE FARM SEPARATOR.}

By the use of the cream-separator a much more perfect separation of the crean from the milk may be had than by any system of gravity creaming. The increased product marle from the saving in loss of fat in skim-milk alone over the best gravity methods of creaming, to say nothing of its other advantages, amounts to from $\$ 5$ to $\$ 10$ per year for each cow. It is obrious, then, that the separator will soon par 
for itself, and will make dairy-work a source of profit and satisfaction instead of drudgery.

Other advantages are: A richer and more uniform quality of cream may be obtained; the skim-milk is in the very best possible condition for feeding young stock; and the cream being always fresh and sweet, its care and ripening is under a more direct control of the butter-maker.

Which is the best separator at the present time it is impossible to say, since no one separator comprises within itself all the points of merit that the ideal separator might possess. All the separators on the market will do efficient skimming if properly handled.

The chief points of merit that should be looked for in a separator are: (1) Strength and simplicity of construction; (2) cheapness and durability; (3) minimum need of power and maximum capacity; (4) thoroughness or closeness of skimming; (5) strength of foundation and steadiness of motion; (6) freedom of defects in its mechanism; and (7) ease of cleaning and general convenience of detail.

Select a separator with a capacity of not less than 50 to $75 \mathrm{lb}$. per hour for each cow milked. A ten-cow herd would then require a machine having a capacity of 500 to $750 \mathrm{lb}$. per hour. Larger herds at same ratio. It is a great mistake to purchase a machine that is too small, as it will take too much valuable time to skim the milk.

\section{LOCATION OF CREAM SEPARATOR.}

When a separate milk-house is available, the cream-separator should always be found there, and never operated in the stable or any other place where the air is impure or the surroundings bad. A simple, clean room with a solid floor and screened doors and windows can be made to answer very well as a place to separate cream.

\section{CARE OF THE SEPARATOR.}

To give a separator the necessary stability it should be fastened to a solid floor or foundation. Care should be taken to have the top of the separator stand level in all directions, and to have it securely fastened to the floor or foundation by means of screws or bolts. A small square of $1 / 4$-inch rubber-sheet packing placed under the outside edge of the base, or under each leg, before fastening improves the running of any separator.

Before the separator is started all parts should be thoroughly cleaned and all bearings well oiled, and oil-cups and oil-holes free and in working condition. Special attention should be given to the oil that is used. With each machine that is sent out by the makers there is sent a can of oil of a quality that has been found by experience to answer the purpose best. Such oil can be obtained from the selling agents of the machine, and no other should be used.

Two or three minutes should be taken to get the speed up to the required rate, which is stated on the crank of the machine. The speed of the machine must then be maintained according to the directions. The only reliable way to do this is to count the number of revolutions of the crank by the watch.

A small quantity of water at a temperature of $110^{\circ}$ to $120^{\circ} \mathrm{Fahr}$. should be used to warm and wet the bowl, and after speed has been acquired the flow of milk may be turned on. In turning a separator by hand we should take care to have the motion as steady as possible. The pressure on the crank should be the same all the way around.

In skimming, three things must be carefully observed-viz., the speed of the bowl, the temperature of the milk, and the feed of the milk to the machine. With the same machine and all other conditions the same, a greater loss of butter-fat must be expected when the separator is not run up to the required speed, when the milk is below a certain temperature, or when more than a certain amount of milk is run through in a given length of time. 
Milk separates best when fresh or new and at a temperature of $90^{\circ}$ to $100^{\circ}$ Fahr., and for this reason the best time to separate the milk is immediately after milking. A low temperature will cause a loss of fat in the skim-milk.

Every separator has some device for changing the test of the cream. In most cases the adjustment is at the cream outlet. If so, by turning the screw in the cream will be richer, and by turning it out the cream will be thinner.

Variation in the percentage of fat in the cream may be caused, also, by a variation in the temperature of the milk; by the quantity of milk in the supply-can; a variation in the percentage of fat in the milk; by irregular speed; and by the bowl not being properly cleaned.

\section{CLEANING THE SEPARATOR.}

Many dairymen are neglectful in the cleaning of the separator, and some seem to think that it is unnecessary to wash the machine more than once a day. Such practice cannot be too strongly condemned. Even when the bowl is rinsed with warm water, there remains a coating of slime and milk on the interior parts which readily undergoes decomposition. When next used, the warm cream in passing becomes contaminated with bacteria from this source, and it is injured beyond repair. Such cream may be dangerous to health, and it is certainly unfit for butter-making.

\section{COLLECTING THE CHURNING.}

The cream-can should be of sufficient size to hold a supply large enough for one churning.

Cream should be churned at least twice a week during cold weather and three times a week during warm weather.

When collecting cream for a churning, great care must be taken to keep it in a cool, clean place, and to stir it thoroughly from the bottom of the can every time fresh cream is added, and frequently until churning-time. A simple and cheap stirrer (Fig 5) consists of a saucer-shaped piece of heary tin about 3 inches in diameter, with a long handle of $1 / 4$-inch heavily tinned iron fastened to the centre of it. No amount of washing and boiling can licep a wooden stirrer suect and clean, and such should on no account be used.

When shallow-pan setting has been used, the cream is already ripened, or partially so, when taken off. If it has been kept cool and properly stirred as each skimming was added, it may be churned almost at any time when brought to the proper temperature.

Cream from a properly conducted deep-setting system should be cold and sweet when skimmed. Fach skimming should be thoroughly stirred when added to the previous lot and kept at a low temperature until twenty-four to thirty-six hours previous to churning, and no fresli cream should be added during the ripening process.

If a cream-separator is used, the cream should be immediately cooled to $55^{\circ}$ Fahr. or less, by setting it in cold or rumning water, or by allowing it to run over a cooler (Fig. 6)

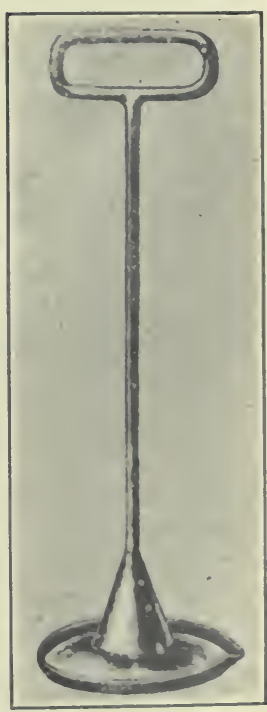

Fig. 5. Cream-stirrer. such as are especially made for that purpose. After thoroughly cooling each skimming it can be added to the main supply. In no case should warm cream be added to cold cream. Both should be equal in temperature, and then they may be mixed together by efficient stirring. The cream should be kept in as nearly sweet condition as possible until enough for a churning has been gathered. 


\section{RIPENING THE CREAM.}

In order to ripen cream properly, the temperature must be made favourable to the development of the lactic-acid bacteria. This temperature is usually somewhat above $60^{\circ} \mathrm{Fahr}$. The object of ripening or souring the cream is to produce flavour and aroma in the butter, to get a more exhaustive churning, and to improve the keeping qualities of the butter. 'These flavouring substances, so far as known, can only be produced by a process of fermentation. The best flavour in butter is obtained when the cream assumes a clean, pleasant, acid taste during the ripening. For this reason it is essential to have acid-producing germs predominate during the ripening process; all other germs should be excluded, or at least retarded, if possible.

Cream ripened at a low temperature $\left(60^{\circ}\right.$ to $70^{\circ}$

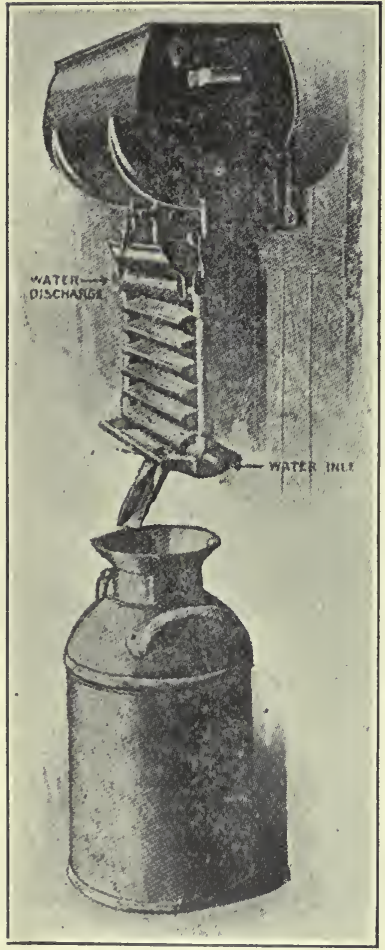

Fig. 6. A good type of cooler. Fahr.) does not sour very rapidly; the germs do not multiply at a very rapid rate. The desired degree of acidity is approached very slowly, and in consequence the fermentation may be checked almost at once when desired. The chance of getting overripe cream is thus reduced to a minimum. If the cream is ripened at a high temperature $\left(75^{\circ}\right.$ to $80^{\circ}$ Fahr.) there is danger of getting overripe cream, which makes a strongflavoured butter with poor keeping quality. Extreme and rapid changes of temperature should be avoided as much as possible. A good thermometer (Fig. 7) should be used in every well-regulated dairy. The more uniform the temperature can be kept, if suitable for proper ripening, the better the results.

There are two ways of ripening cream; the first is to allow it to sour naturally, as a result of the action of the bacteria which are normally present in the cream. By the second method the cream ripens as a result of the action of certain kinds of bacteria which are added in what we know as a "starter," or pure culture.

A "starter" is milk which has been properly soured, has a pleasant, clean, acid flavour, and is capable of producing a similar flavour in the cream to which it is added. The object of its use is that the bacteria which you know will produce a fineflavoured butter may take possession of the sweet crean before other and perhaps objectionable germs gain control of it. Buttermilk or sour cream from a previous churning are sometimes used, but their use is not to be recommended, for the reason that, even though the flavour is good, there are always present some undesirable germs which will multiply in each suc-

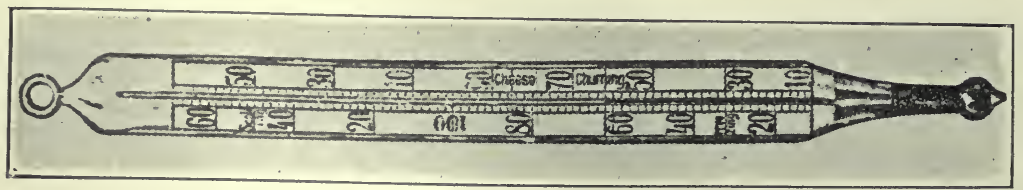

Fig. 7 . Floating dairy thermometer. Makes definite knowledge of temperature possible.

cessive lot of cream or buttermilk used as a starter, so that after a week's time the flavour may actually be bad. When cream is slightly off-flavoured, and a portion of this, or the buttermilk from it, is used as a starter, it will readily be seen that the taint will not only be transmitted, but will increase from day to day. 
The best natural starters are made by allowing the bacteria normally found in the milk to sour or curdle it. They may be made by taking a small quantity of skimmilk or whole milk, produced under clean conditious from clean cows, while fresh and new, and allowing it to sour naturally in a well-sterilized glass jar at a temperature of from $70^{\circ}$ to $80^{\circ}$ Fahr. If it sours normally, with a pleasant, clean, acid flavour, it may then be added to the cream at the rate of about $1 / 2$ to 1 pint for each gallon of the cream to be ripened.

Generally speaking, the most satisfactory method of ripening cream under arerage farm conditions is to keep it as sweet as possible until about twenty-four to thirty-six hours before churning-time, and then slowly bring the temperature up to $65^{\circ}$ to $70^{\circ} \mathrm{Fahr}$. by standing the cream-can in a tub of warm water, and when it has ripened sufficiently to produce an acid smell and a slight acid taste and shows signs of thickening, it should be at once thoroughly and quickly cooled to churning temperature and held until churning-time. It is always best to time the ripening so that the cream may be cooled ready for churning about eight to twelve hours before churning takes place. This is necessary to give the fat in the cream time to become firm, or the result will be a soft, weak-textured butter.

Should it become necessary to use a starter in order to hasten the ripening process, as may happen during cold weather, one made from skim-milk or whole milk as described above will in most cases prove very satisfactory.

One of the most difficult things to determine is when the cream has the proper ripeness to be churned, so that uniform results can be obtained and one churning be like another. A skilful, experienced butter-maker is able to judge very closely the right condition of the cream for churning by its appearance. A properly ripened cream should have a clean, sharp, pleasant, acid taste and smell, and should be of the consistency of good molasses, and when poured be free from lumps and have a smooth, glossy appearance.

\section{CHURNING TEMPERATURE.}

The proper temperature for churning cream can be determined only by the length of time it takes to bring the butter in a firm, granular form. This should be from twenty-five to forty minutes. There are a number of factors which influence the churning temperature of cream, chief of which are: (1) The percentage of fat in the cream; (2) the period of lactation of the cows; (3) the feed of the cows; (4) the amount of cream in the churn; and (5) the speed of the churn.

\section{Richiness of the Cream.}

The closer the fat-globules are to each other, the more quickly they will unite, with the same amount of concussion in churning. In a rich cream the fat-globules are very close together, which render it more easily churnable than thin cream, and can therefore be churned at a lower temperature in the same length of time. The lower temperature is favourable for a firm, waxy-grained butter.

To get the best results, the percentage of fat in the cream sliould range from 25 to 30 per cent., or about 3 to $3 \frac{1}{2} \mathrm{lb}$. of butter to each gallon of cream churned.

\section{Period of Lactation.}

The length of time the cows have been in milk influences the churning temperature, because of its effect upon the size of the fat-globules in the milk. In the earlier part of the milking period cows produce milk containing larger fat-globules.

\section{Feed of the Cows.}

'The effect of the feed of the cows is due to its effect upon the composition of the fat-globules. Suceulent feeds, like pasture grass, green corn, silage, roots, etc., tend to increase the softness of the fat-globules, while dry feeds, such as hay, grains, etc., cause a harder butter-fat. 


\section{Amount of Cream in the Churn.}

The fullness of the churn affects the amount of agitation that is possible during the revolution of the churn. The best and quickest churning is secured when the churn is about one-third full. With more or less cream than this, the amount of concussion is reduced, and the length of time in churning correspondingly increased.

\section{SPEed oF THE ChurN.}

The speed of the churn also affects the amount of agitation the cream receives. It should be such that the cream receives the greatest amount of agitation or concussion. Too high or too low a speed reduces the amount of concussion.

In general, it may be said that rich separator cream may be churned at $48^{\circ}$ to $52^{\circ}$ Fahr. in summer and $50^{\circ}$ to $55^{\circ}$ Fahr. in winter. Gravity cream requires a temperature of $55^{\circ}$ to $60^{\circ} \mathrm{Fahr}$. in summer and $60^{\circ}$ to $64^{\circ} \mathrm{Fahr}$. in winter. A good rule to follow is this: When the cream enters the churn, the temperature should be such that the cream will churn in nice granular form in from thirty to forty minutes. This will ensure an exhaustive churning and leave the butter in a condition in which it can be handled without injuring its texture. Moreover, the buttermilk can then be more thoroughly drained off, and the butter requires less washing.

\section{CHURNING.}

Before adding the cream, the churn (Fig. S) should be scalded with hot water, and then thoroughly cooled with cold water. This will freshen the churn and fill the pores of the wood with water, so that the cream and butter will not stick.

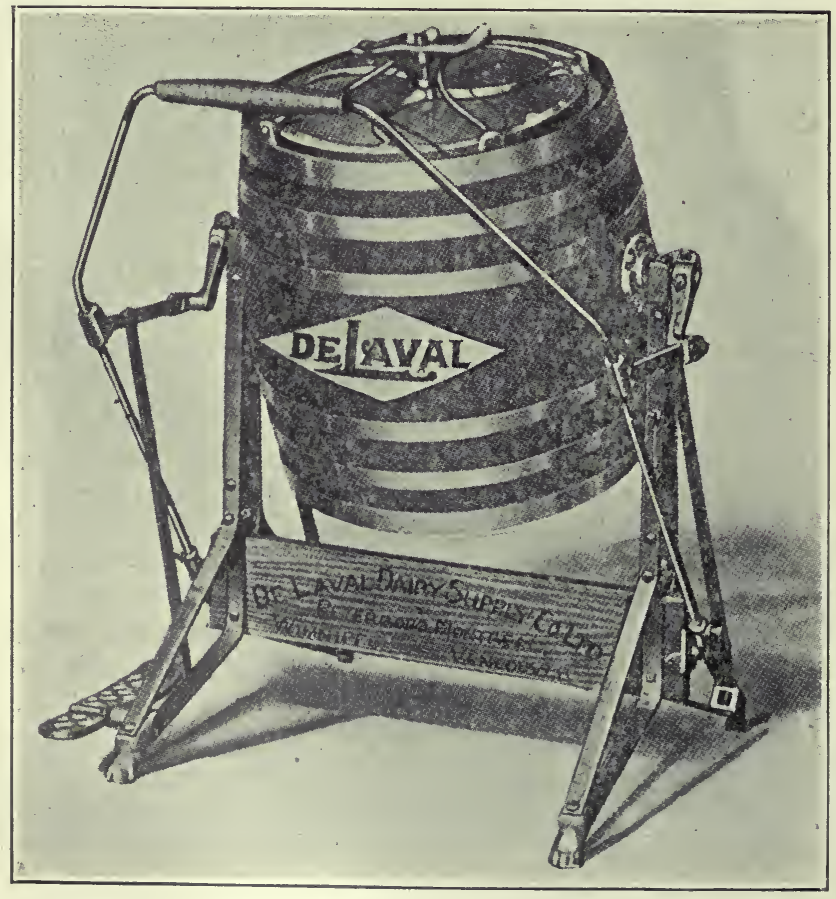

Fig. 8. A good type of hand-churn.

\section{Straining.}

All the cream should be carefully strained into the churn through a finely perforated tin strainer (Fig. 9). This will break up or remove all clots of cream and 
particles of curd, and there will be less danger of white specks in the butter. These particles injure both the appearance and keeping qualities of the butter.

\section{Colouring.}

When colouring is used it should be added before churning commences. In summer in times of drought, and in the fall and winter when cows are on dry feed, some colouring may be needed. The general market now demands a butter with a clear, light-yellow tint. Too deep a shade is repulsive. From two to four drops of any good, reliable brand of colouring per pound of butter will be sufficient. In case the colour is not added to the cream (through an oversight), it may be mixed with the salt and added to the butter at the time of working. When the coloured salt has been evenly distributed through the butter by efficient working, the colour

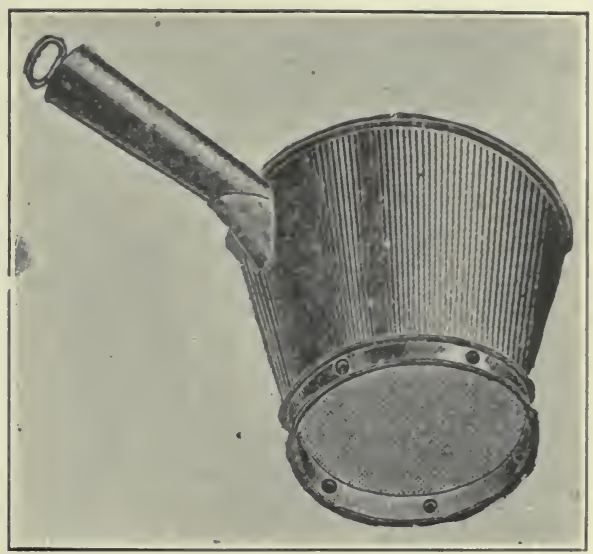

Fig. 9. Cream and buttermilk strainer. will be found uniform throughout.

\section{Gas in Churn.}

During the first five minutes of churning, the vent of the churn should be opened occasionally in order to allow the cream-gases and expanded air to escape.

\section{WheN TO STOP CHURNiNg.}

This is a very important point which has a good deal to do with the quality of the butter. At the time the butter breaks, the churn must be carefully watched in order that the fat-globules may mass together in granular form, so that the buttermilk may be thoroughly removed, and this can best be accomplished if the butter gathers in the form of granules varying in size from that of wheat to peas. Their size can be best controlled by stopping the churn frequently after the butter brealis. If the gathering process is coming on quickly, several quarts of cold water should be added to the cream. This retards the gathering, lessens the chance of orerchurning, and gives a more exhaustive churning. On the other hand, if the butter gathers too slowly, or remains about the size of clover-seed, several quarts of water which is a little higher in temperature than the cream may be added, and the churner revolved a few times. It should now stand for several minutes, after which a part of the diluted buttermilk may be drawn off and the churning continued.

Churning is completed when the butter stands well out on top of the buttermills with froth bubbles over it, and when no butter comes with the first drawn buttermilk.

\section{WASHING THE BUTTER.}

After churning is completed, the buttermilk should be drawn off at once and the butter allowed to drain for a few minutes. The butter should then be washed with pure, clean water, and its temperature should be somewhere near that at which the buttermllk was, depending upon the firmmess of the butter. If too soft use colder water, and if too hard use water which is a little warmer. The main objects of washing the butter are to rid it of all the buttermilk possible, to improre its keeping quality, and to firm or harden it so that it can be thoroughly and efficiently worked without injuring its grain and texture. The amount of water used should be equal to the amount of cream churned, and this should always be carefully strained into the churn through a good cotton strainer. 
If the butter is of fine flavour and for immediate use, one washing will generally be sufficient; otherwise it is well to wash twice, especially if the butter is to be held for some time. Bad-flavoured butter cannot be washed too much.

\section{SALTING THE BUTTER.}

After the wash-water has been thoroughly drained off the butter it should be salted to suit the requirements of the consumer. The butter-maker must cater to the market with regard to the amount of salt to use. As a general rule, however, for prints, $1 / 2$ to $3 / 4$ oz. per pound should be used, and for packed butter not more than $1 \mathrm{oz}$. per pound.

Salt adds flarour to butter, serves more or less as a preservative, and assists in expelling the buttermilk. The butter may be salted either in the churn or on the butter-worker.

\section{Salting in the Churn.}

If the amount of butter in the churn can be fairly accurately estimated, it may be salted in the churn while in the granular form. This can best be accomplished by sifting on half of the salt evenly over the butter, then turn the butter over with a ladle, or by tipping the churn forward cause the butter to lap over. The remainder of the salt may then be sifted on, and after tilting the churn backward and forward several times the cover should be put on and the churn revolved slowly until the butter is gathered into a solid mass. It may then stand for a few minutes to allow the salt to dissolve, after which it may be worked.

\section{SaLting ON THE Worker.}

If the butter is to be salted on the worker, it should be taken out of the churn in the granular form, carefully weighed, and spread evenly on the worker. The required amount of salt should also be carefully weighed, and sifted on the butter as evenly as possible, doing it in three or four applications, turning the butter each time.

\section{WORKING THE BUTTER.}

The best way to work butter, outside of the combined churn, is to use a V-shaped table worker (Fig. 10). One working at the time of salting is usually sufficient,

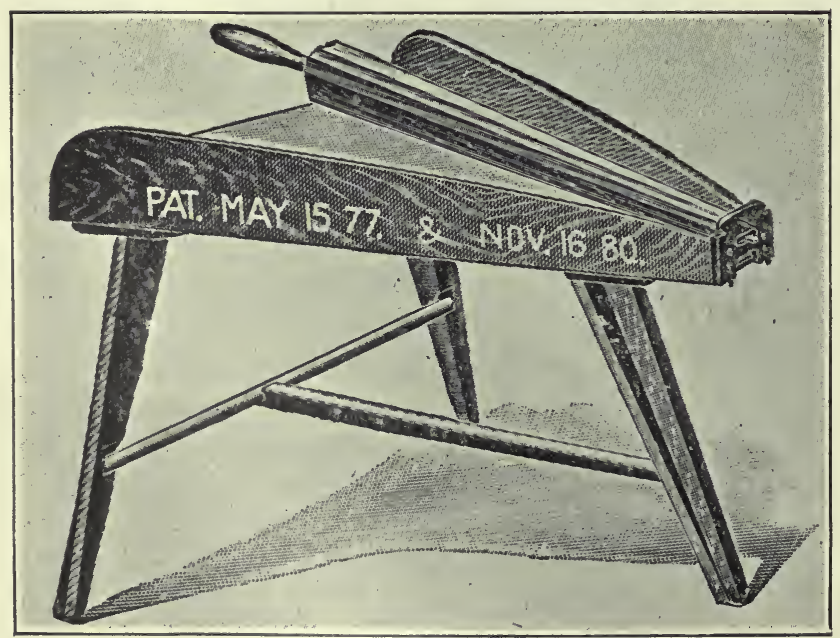

Fig. 10. Lever butter-worker.

provided the butter is firm enough when taken from the churn and worked in a cool place. 
The purposes of working butter are: (1) To assist in distributing the salt through the butter; (2) to assist in expelling buttermilk and moisture; and (3) to produce a compact, firm, close-textured body.

In working the butter, care must be taken to avoid a sliding or scraping motion, which makes the butter greasy. The lever should be pressed downward, turning it slightly over by a movement of the wrist; and when the butter is levelled over the worker, (louble it over with a ladle (Fig. 11) or by inserting the lever under the butter at one side of the worker, and work as before.

The proper amount of working to be given to the butter will be best ascertained by observing the results of different amounts under the one system for successive days. It is worked enough when the salt has been evenly distributed and the excess of free moisture expelled. It should have a firm, glossy appearance, and the texture should resemble the granular structure of the end of a broken rod of steel. Underworking is generally shown by a mottled appearance in colour on the cut surface, and is largely due to an uneven distribution of salt, while overworking is indicated by a poor, greasy grain and texture.

\section{MOTTLED BUTTER.}

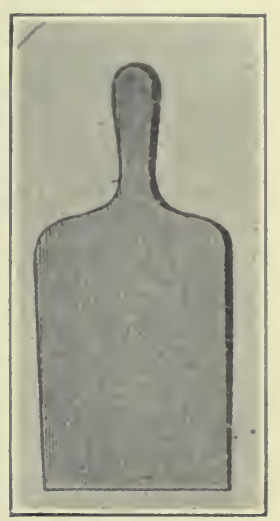

Fig. 11. Wooden ladle. Butter should not be touched with the hands.

Next to inferior flavour in butter, mottles are most objectionable to the consumer, since they affect the appearance and often give the impression that the butter is very bad, when, in reality, its flavour may be good. This defect is one of workmanship, and can be overcome by the application of proper methods on the part of the maker.

Mottles are primarily caused by an uneven distribution of salt in the butter. This may be produced by insufficient working of the butter, or by washing and working at a rery low temperature. Extremely low temperature for washing and working should therefore be avoided, because they produce so firm a butter that it is only with great difficulty that the salt can be worked uniformly into it. On the other hand, high temperatures of churning, washing, and working must also be avoided to prevent an abnormal loss of fat in the buttermilk and the making of a greasy, salvy, or leaky butter.

Generally speaking, the butter should be uniform in temperature and from $52^{\circ}$ to $56^{\circ} \mathrm{Fahr}$., in accordance with the weather conditions, so that it will stand a good deal of working without becoming too soft and greasy. Hard butter must be worked more than soft butter, and a small quantity more than a iarge quantity.

When the churn-room is so cold that the butter becomes chilled before working is completed, mottled butter is frequently the result. To prevent this it is preferable to increase the amount of working rather than to raise the temperature of the wash-water.

\section{PACKAGES.}

The greatest lack of uniformity in dairy butter is probably in the package. In the past, butter has frequently been put up in all sizes, shapes, and forms, wrapped in all sorts of materials, such as cheesecotton, factory-cotton, towels, paper, and some not

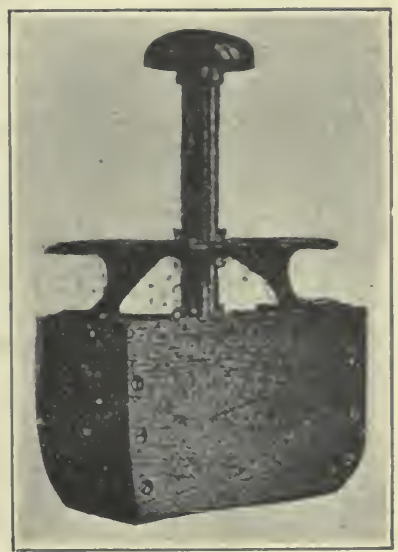

Fig. 12, One-pound butterprinter. Makes a neat, attractive package. 
should be the aim of every butter-maker to turn out butter that is neat and attractive in appearance, as well as of first quality. The most desirable package, and one that can be always neat and attractive, is the 1-1b. print or brick, neatly wrapped in parchment paper. The printer (Fig. 12) should be set to give prints weighing full $161 / 8$ oz., and only the best quality of pure vegetable parchment paper should be used. The name of the farm or dairy should be neatly printed on the paper.

No're--In order to comply with the "Dairy Industry Act, 1914," the following regulations must be observed:-

"Sec. 14. No person shall knowingly sell, offer, expose, or have in his possession for sale-

"(e.) Any dairy butter packed in boxes similar to those used for the packing of creamery butter unless such packages are branded 'dairy butter':

“(f.) Any dairy butter packed, moulded, or cut into blocks, squares, or prints and wrapped in parchment paper unless such parchment paper is branded "Dairy Butter.'

"'The words 'Dairy Butter' must be in letters at least one-quarter inch square."

'The full text of the "Dairy Industry Act, 1914," and the regulations made thereunder are published as Bulletin No. 42, Dairy and Cold Storage Series, which may be obtained free upon application to the Publications Branch, Department of Agriculture, Ottawa.

For packed butter, the 10 - or 20-1b. spruce tub lined with parchment paper is probably the neatest and most attractive package.

Stone crocks varying in size from $1 / 2$ gallon up, if well glazed and in good condition, also make excellent containers for packed butter for local trade.

\section{PREPARATION OF CHURN, ETC.}

In the preparation of woodenware, such as the churn, worker, and ladles, for use in the dairy, the following points should be observed: 'They should first be scrubbed with a brush and scalding water, and then thoronghly cooled by pouring on cold water. If the butter sticks to the wood, it indicates that it has not been properly prepared. A thorough brushing with hot water and scouring with salt before cooling will remedy this trouble.

\section{UTENSILS.}

All milk-pails and other dairy utensils used in handling milk and cream should be of such construction and material that they can easily be kept clean. Many are to be found in use with open or rough seams and joints, so that the milk can never be completely removed from them by any ordinary methods of washing, and it remains there to sour and decay, inoculating each milking with millions of the most undesirable bacteria. The use of sound utensils, well timned, free from rust, and in a cleanly condition, is essential to good milk. Dented or battered pails, cans, etc., and seams that are not properly flushed with solder camnot be readily cleaned. Such meven surfaces invite contamination that is readily imparted to the milk, though the latter is subjected to it only for a very short period. New pails and cans may cause an immediate improvement in the product.

An essential requirement in any utensil for handling milk is simplicity, to which should be added durability. Nothing will contribute so much to the cause of batter milk and cream as will the sanitary milk-pail, if properly used and cared for. The critical period in the life of milk is during the time of milking. Very few who have not made careful tests realize to what extent the wide-open pail invites dirt as compared with one partly covered. These assist very materially in excluding dirt and dust, and when we fully realize that dust-particles are the carriers of infection, the advantages of excluding them are obvious. Milking-pails should never be used for any other purpose. 


\section{WASHING DAIRY UTENSILS.}

This is a very important question, though it involves but a few simple considerations. They should be rinsed first of all with cold or lukewarm water to remove all particles of milk. 'This step should never be omitted, for hot water tends to cook the milk fast to the tin, forming a sticky layer over the surface which is very diflicult to remove. They should then be thoroughly scrubled with a brush in warm water to which a small quantity of good washing-powder, such as "Wyandotte" or "Crescent Cleamer," has been added. 'The washing should be followed by a thorough scalding with water as near the boiling-point as possible, after which the vessel should be inverted on a rack to drain and dry from their own heat. With the exeeption of woodenware which might crack or warp, all utensils should if possible be placed where the sun will shine on them, in a dust-free atmosphere, as that will do much towards keeping them pure and sweet.

'The protection of utensils from accidental contamination after they have been thoroughly washed and scalded has a measurable effect in reducing the germ content of the milk or cream.

VICTORIA, B.C. :

Printed by WilliaM H. CrLlin, Printer to the King's Most Excellent Majesty. 1916. 






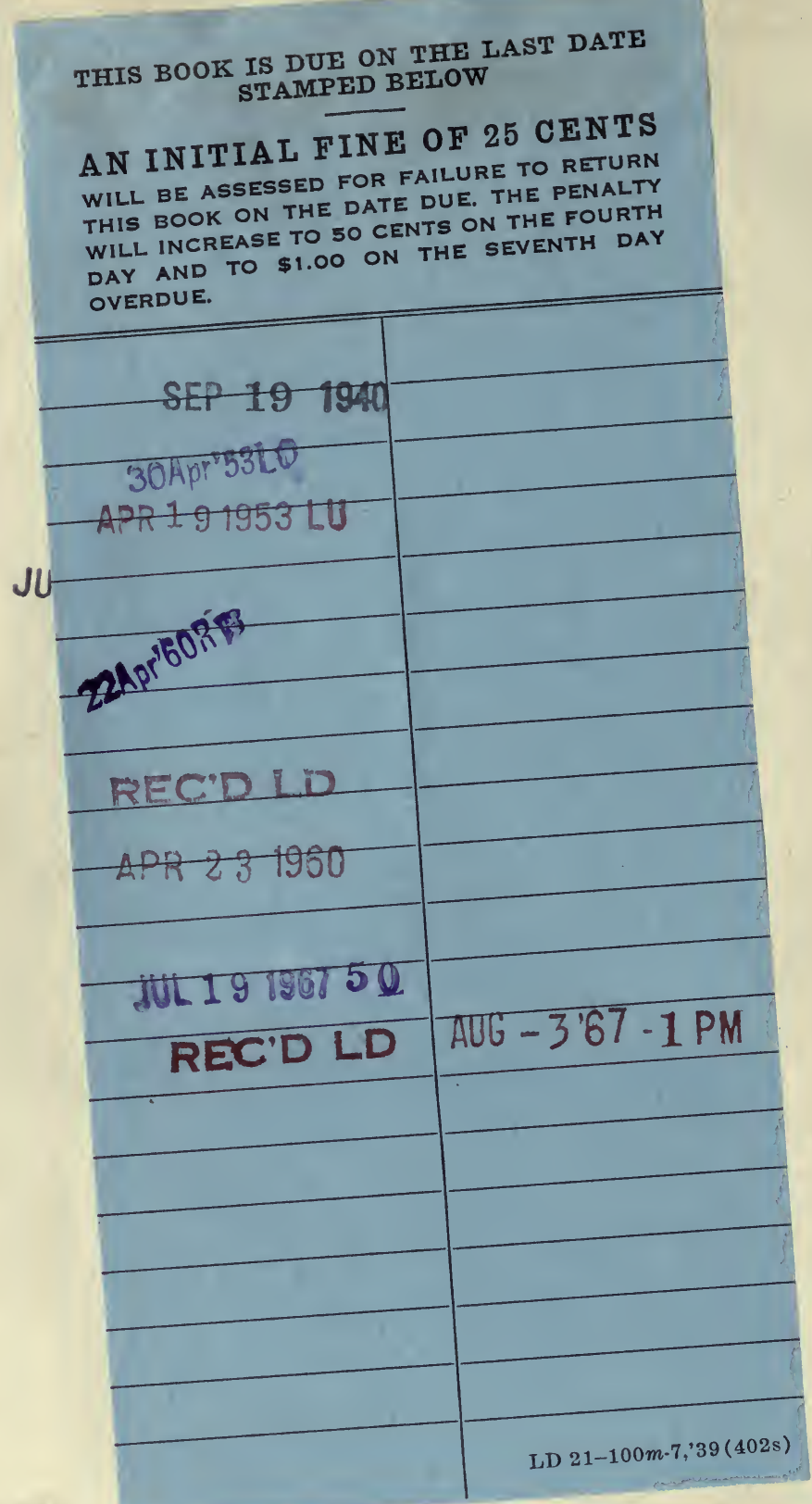




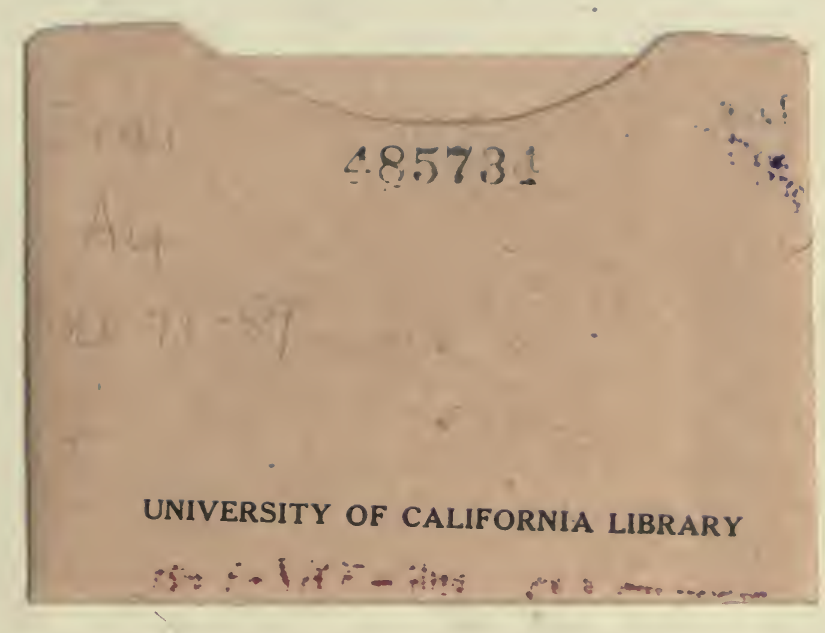


